\title{
Responsibilities Head of The Village And Village Chairman on Register Book of Land For The Achievement of Justice Land Administration Regulations
}

\author{
Lina Maulidiana ${ }^{1}$, Rendy Renaldy ${ }^{2}$ \\ \{maulidianalina17@gmail.com ${ }^{1}$,rendynotaris@gmail.com² ${ }^{2}$.gm \\ Law Faculty, Sang Bumi Ruwa Jurai University, Bandar Lampung, Lampung ${ }^{1}$, Law Faculty, Sang Bumi \\ Ruwa Jurai University, Bandar Lampung, Lampung ${ }^{2}$
}

\begin{abstract}
Land is one of the earth's assets that has high value because it has an important role and function that cannot be separated from human life. The state's recognition of land rights owned by the community as legal subjects that give rise to control over land makes the State obliged to guarantee legal certainty of land rights by conducting land registration for the first time by issuing certificates as proof of ownership of land rights. The head of village and the Village chairman play an important role in supporting the land registration process for the first time with their land registration book (Letter $\mathrm{C}$ ). However, a legal issue arises when in collecting land data, whether the land data at the village level has been filled in properly, correctly, completely and always up to date, and is well maintained because there is a possibility of a plot of land, the existing data is only found in the land register book at the village head and village. If the data is not properly maintained, there is an opportunity for land disputes to arise in the future. This study uses a normative juridical approach or normative law. This research method is a literature law research method where the method or method used in legal research is carried out by examining existing library materials. The answer to the research problem regarding the responsibilities head of village and the village chairman in the land register book for the achievement of a just land administration is criminal responsibility, namely based on the Criminal Code, Articles relating to land crimes include crimes against land grabbing which are regulated in Article 167 of the Criminal Code, Crimes against forgery of documents are regulated respectively in Articles 263, 264, 266 and 274 of the Criminal Code as well as crimes of embezzlement of rights over immovable property such as land, houses, rice fields. This crime is commonly referred to as stellionaat crime, which is regulated in Article 385 of the Criminal Code. Liability in a civil manner, namely by using or applying the principle of unlawful acts or onrechtmatige daad applicable in Article 1365 of the Civil Code as well as administrative sanctions based on the provisions in Law Number 6 of 2014 concerning Villages, namely in the form of warnings, temporary notification until permanent dismissal from the position of Village Chairman.
\end{abstract}

Keywords : Village Heads, Land Registry Book, Orderly Land Administration.

\section{Introduction}

Ownership of land is a basic right of every Indonesian citizen as regulated in Article 28 letter H of the 1945 Constitution of the Republic of Indonesia which states that everyone has the right to private property and these rights cannot be taken over arbitrarily by anyone. The state guarantees the right of its citizens to own private property, including land rights. The guarantee was subsequently born on the basis of the right to control the state adhered to in Article 2 of Law Number 5 of 1960 concerning Basic Agrarian Principles which explains that 
the earth, water and space including the natural wealth contained therein are controlled by the state at the highest level [1].

Land is one of the earth's assets that has high value because it has an important role and function that cannot be separated from human life. The state's recognition of land rights owned by the community as legal subjects that give rise to control over land makes the State obliged to guarantee legal certainty of land rights by conducting land registration for the first time by issuing certificates as proof of ownership of land rights. Regarding registration activities for the first time it is regulated in Article 1 number 9 Government Regulation Number 24 of 1997 concerning Land Registration which explains that land registration for the first time is an activity carried out on objects of land registration that have not been registered under Government Regulation Number 10 of 1961 concerning Land Registration. or this Government Regulation [1].

Physical and juridical data are collected in the process of registering land for the first time, one of which is obtained from the data contained in the land register book at the Village level, this shows how important land data is recorded in the village level land register book. A land register book at the village level is a land register that contains the subject of rights, objects of rights, rights itself as well as legal actions regarding land administered by the village government. The land data that is in the land register at the village level becomes the preliminary data for the sporadic land registration process. What is meant by sporadic land registration is the activity of registering land for the first time regarding one or several objects of land registration within the territory or part of a village, individually or in bulk [2].

This process requires supporting data such as girik or land letter $\mathrm{C}$ obtained from the village level land book register, in accordance with the provisions in Article 76 of the Regulation of the State Minister for Agrarian Affairs / Head of the National Land Agency Number 24 of 1997.

The problem faced in collecting land data is whether the land data at the village level has been filled in properly, correctly, completely and always up to date, and is well maintained because there is a possibility for a plot of land, the existing data is only found in the village level land register book. If the data is not properly maintained, it will open up opportunities for disputes or land problems that will arise in the future, to ensure that the actual land owner of land parcels that has not been certified or that has been certified, this could happen due to the process of land ownership and control in particular. in villages that occurred before the LoGA was generally not supported by complete written evidence because the transfer of rights (buying and selling, grants, exchange, inheritance or release of rights) in the community was sufficiently carried out in front of or known to the village head who was not only acting as a witness but also in his position as customary head who bears that the transfer of rights does not violate the applicable law.

The transfer of rights in this way is of course easy to cause disputes, especially because there is no deed of transfer of rights before the Official of the Land Deed Maker as required in the statutory regulations that: Transfer of land and ownership rights to apartment units through sale and purchase, exchange, grant, entry into the company and other legal acts of transfer of rights, except the transfer of rights through an auction, can only be registered if it is proven by a deed made by the authorized Land Deed Making Official according to the provisions of the prevailing laws and regulations.

The increase in land disputes is not only caused by the increasing need for land for development, but also because the need for land for development continues to increase, because complete land data is not yet available at the village level [3]. 
The land data that is in the land register at the village level becomes the preliminary data for the sporadic land registration process. What is meant by sporadic land registration is the activity of registering land for the first time regarding one or several objects of land registration within the territory or part of a village, individually or in bulk. In general, the objects of sporadic land registration in Lampung are customary land, cultivated land, explantation land or state land either through the process of recognizing rights or applying for rights.

For this process, supporting data is required including girik or a copy of letter C obtained from the village-level land book register, in accordance with the provisions in Article 76 of the Regulation of the State Minister for Agrarian Affairs / Head of the National Land Agency Number 24 of 1997.

The girik is actually a tax imposition letter and a tax payment receipt or landrente on behalf of the land owner which is considered among the people and is treated as proof of ownership of the land which he has bought has not been reversed. During the period 1981 to 1985 the number of certificates issued through sporadic land registration was recorded at an average of 250,000 certificates per year, and it is likely that in its development the issuance of certificates will increase. In line with the stipulation that only land with customary ownership status is subject to Indonesian landrente or verponding, as well as the desire and effort of people to have a tax return with themselves as taxpayers, justifies the practice of using the data contained in the tax receipt as a strong indication of the status the land is a customary property and the taxpayer is the owner. This fact can be used as an element to assist in affirming the conversion of customary ownership rights to property rights according to the UUPA regarding lands for which registration is requested according to Government Regulation Number 24 of 1997 concerning Land Registration.

Land registration that is carried out results in a land title certificate which is a strong means of proof as stated in the provisions of Article 19 paragraph (2) letter C, Article 23 paragraph (2) Article 32 paragraph (2) and Article 38 of the Basic Agrarian Law. The certificate is only a strong proof and not a perfect proof according to the provisions of the UUPA and government regulations that implement it, this means that the information contained therein has legal force and must be accepted by the judge as true information as long as and as long as it does not exist. proving tools that prove otherwise.

In fact, it is not easy to carry out sporadic land registration because most of the ownership or ownership of the land is not supported by evidence tools that are easy to obtain and can be trusted to be true, therefore errors often occur in the issuance of certificates, resulting in disputes over ownership and boundaries. or even more than one data from land parcels where land registration has been completed.

The occurrence of more than one plot of land with different numbers with an area and / or on behalf of the same or different people, and it is shown in the same location but the basis / instructions for certification (Letter c) are different.

Based on the background of the problem above, it is deemed necessary to formulate a problem regarding the responsibilities of the Lurah and the Village Head in the land register book in order to achieve a just land administration order.

\section{Methods}

This study uses a normative juridical approach or normative law. This research method is a library law research method where the methods or methods used in legal research are carried out by examining existing library materials.[4] The first stage of normative legal research is 
research aimed at obtaining objective law (legal norms), namely by conducting research on legal issues. The second stage of normative legal research is research aimed at obtaining subjective law (rights and obligations).[5]

The relevance of this research approach is to analyze and examine the problems that are the object of research, namely responsibilities head of the village and village chairman on register book of land for the achievement of justice land administration regulations.

\section{Result and Discussion}

The transfer of rights to former customary land requires a Letter $\mathrm{C}$ or girik, as well as a statement from the Village Head regarding the land, which information is given by the Village Head / Lurah. Based on the records contained in the village level land register books, especially the land book, the land ownership register book and the land title transfer book, from the records contained in the village-level land register books in particular, the land ownership register book and the book transfer of rights to the land. Based on the records that correspond to the register of the Village Head / Lurah Issuing a Certificate of Non-Dispute and Certificate of Land History which contains the original subject of the land owner up to the control by the subject at the time the letter was made, the status of the land, the location of the land, the area and boundaries as well as regarding transfer of right [6].

If previously there was a transfer of rights from the previous owners either with an underhand transfer deed or with the Deed of the Land Deed Making Official. The correctness of the data in the village level land register book depends on the filling it is done, namely whether it has been done correctly and the maintenance of the data is carried out continuously, so that it becomes land data that is guaranteed to be true, can be accounted for and is always up to date so that it can be used by community members who need and minimize errors which can lead to land dispute problems in the future. The incorrect land data has implications for the physical and juridical data in the land registration process so that the certificate which is the final result of the land registration process can be canceled.

The position as the Village Head / Lurah is obliged to provide services to the community including land issues and has the authority to issue documents needed by the community in his village area, such as a certificate regarding former customary land that is required for land registration for the first time. Furthermore, in Law of the Republic of Indonesia Number 6 of 2014 concerning Villages, the duties and powers of the Village Head are to organize government, development and society to carry out these duties and authorities. Article 15 regulates the obligations of the Village Head including:

1. Obey and enforce all laws and regulations;

2. Carry out a good village government administration;

3. Reconcile community disputes in the village [7].

In carrying out his position to serve the community, the Village Head is required to apply the principle of accuracy by explaining that each Head of Sub-district and Lurah in issuing a Certificate must apply the principle of accuracy.This principle of accuracy is one of the formal principles in the general principles of good governance, this principle of accuracy is intended. that every state administrative officer is indicated that when preparing the issuance of a decision, he must obtain knowledge of all relevant facts and all related interests, not arbitrarily, with respect to the rights of other [7].

Of these duties and obligations the Village Head has a big role and it is easy to misuse or abuse his position, for example not making notes or making incorrect records regarding the 
transfer of rights or providing information against the law or even giving false information, mistakes in carrying out these duties and obligations often occur especially error in providing a certificate so that it is detrimental to the community in need and can even lead to land disputes. For errors in carrying out the duties and obligations of the village head, it can be held accountable, both civil and criminal by the injured community, even though this is not regulated in Government Regulation Number 24 of 1997 concerning Land Registration, this is actually a setback or decriminalization due to this regulation.

Government Number 24 of 1997 concerning Land Registration in Article 44 stipulates that criminal sanctions for violations of the boundaries of a land parcel are stated with boundary signs according to the provisions stipulated by the Minister of Agriculture and violations of the making of deeds concerning the transfer of rights to land, giving a New rights to land, or mortgage rights without being appointed by the Minister of Agrarian Affairs shall be punished with imprisonment for 3 (three) months and or a fine of up to Rp. 10,000, - (ten thousand rupiah). In addition, it is also prohibited for the Village Head to strengthen the agreement regarding land that has been recorded if:

1. The request is not accompanied by a certificate of the land concerned;

2. The land that was the object of the agreement was still in dispute;

3. Not accompanied by documents for payment of registration fees.

Government Regulation Number 24 of 1997 concerning Land Registration does not regulate criminal sanctions for violations that occur in land registration and issuance of certificates, but this does not mean that criminal responsibility cannot be held based on the Criminal Code especially if there is an element of negligence / negligence or fraud and coercion in making a certificate regarding land or physical data and juridical data in land registration.

Mistakes in carrying out the duties and obligations of the Village Head / Lurah can cause harm to the community, especially if it eventually causes a dispute, which losses are not only in the form of suffering economic losses but also related to social, juridical, security, psychological and physical losses. Therefore, the Criminal Code can be applied if there is a violation or crime related to land such as destroying land boundary markers, providing false or untrue information regarding land data containing physical data and juridical data or making a certificate committed by the Village Head / Lurah or Camat and the person applying for the right. The articles of the Criminal Code related to land crimes are applied as follows:

1. Crimes against forgery of documents are regulated in articles 263, 264, 266, and 274 of the Criminal Code, respectively;

2. Civil disputes relating to land issues;

3. Problems relating to the customary rights of indigenous peoples.

In addition to criminal liability, the injured community can also ask for civil responsibility, namely by using or applying the principle of an unlawful act or onrechtmatige daad which applies in article 1365 of the Civil Code, namely that an act against the law can be interpreted as making something or neglecting something that (a) violates the rights of others (b) violates the legal obligation (rechtsplicht) of the person who commits the act, (c) violates both morality and the principles of social association regarding the respect for the self of others or the property of others.

Mistakes in carrying out the duties and obligations of the Village Head / Lurah can lead to land disputes in the Regulation of the State Minister for Agrarian Affairs / Head of the National Land Agency Number 30 of 1999 concerning Procedures for Handling Land 
Disputes, in the article it states that what is meant by land disputes is a difference of opinion regarding :

1. The validity of a right;

2. Granting of land rights;

3. Registration of land rights including transfer and issuance of proof of rights, between interested parties and agencies within the National Land Agency.

Broadly speaking, the map of land problems can be grouped into:

1. Problems with people's cultivation of real forest land, plantations, abandoned housing projects, and so on;

2. Problems relating to violations of the provisions on land reform;

3. Excesses in the provision of land for development purposes [8].

The provisions in the Regulation of the Head of the National Land Agency Number 3 of 2011 concerning Management of the Assessment and Handling of Land Cases do not specifically regulate the cancellation of land rights but are regulated in the provisions regarding the settlement of land cases in Chapter VII by providing an arrangement that basically there are 2 settlement of land cases (two) namely: 1) implementation of court decisions and 2) settlement of land cases outside the court.

The implementation of court decisions and the settlement of land cases outside the court can result in legal action in the form of cancellation of land title certificates so that it can be said that if it is based on the Regulation of the Head of the National Land Agency Number 3 of 2011 concerning Management of Assessment and Handling of Land Cases, cancellation of land rights can be carried out. in two ways, namely: 1) based on a court decision and 2) not based on a court decision.

Article 55 of the Regulation of the Head of the National Land Agency Number 3 of 2011 concerning Management of the Assessment and Handling of Land Cases confirms that actions to carry out court decisions that have obtained legal force can still be in the form of implementing all of the rules of decision, implementing some of the orders of decisions or just carrying out explicit orders. written on the verdict.

Furthermore, in Article 55 paragraph (2) it is stated that the court's verdict has obtained permanent legal force, relating to the issuance, transfer and / or cancellation of land rights.

The land dispute settlement mechanism, according to Rusmadi Murad, is organized with the following pattern:

1. Complaints from parties who feel their rights have been violated. The dispute over land rights arises because of complaints / objections from persons / legal entities containing the truth and demands of a State Administrative Decree in the land sector that has been stipulated by the State administration official within the National Land Agency. where the official decision is felt to be detrimental to their rights over a certain land parcel. With this complaint they want to obtain an administrative settlement with what is called an immediate correction from the competent official for it. That the authority to make such corrections lies only with the head of the National Land Agency.

2. Research by the relevant Land Office on incoming complaints. From the results of this study it can be concluded whether the complaint is reasonable or not for further processing. If the data submitted directly is unclear or incomplete, the National Land Agency will ask for an explanation accompanied by data and advice to the head of the local Regency Municipal Land Affairs Office where the disputed land is located. Furthermore, after the required data is complete, it is then reviewed the proposed problem which includes aspects of procedure, authority and legal application. 
3. Prevention of mutation or transfer of disputed objects, with the aim of temporarily suspending all changes.

4. Deliberation on land disputes submitted by the National Land Agency for resolution, if the disputing parties can meet, then it is very good if they are resolved through deliberation. In this deliberative settlement, the National Land Agency is often asked to act as a mediator in resolving land rights disputes peacefully with mutual respect for the disputing parties. If there is peace, it must also be accompanied by written evidence at the beginning, namely a notification letter to the parties, Minutes of the Meeting and thereafter as evidence of a peace statement written in a Notary Deed so that it has perfect evidentiary power.

5. Revocation / cancellation of the State Administrative Decree in the Land Sector by the Head of the National Land Agency based on an administrative law flaw in its issuance.

In practice, so far there are many legal persons / entities who feel that their interests are being harmed by filing direct objections to the head of the National Land Agency. Likewise, an application for the cancellation of a land certificate is based on a court decision that has permanent legal force.

Most of these are submitted directly by the person concerned to the Head of the National Land Agency and some are submitted to the head of the local Municipal / Regency Land Office and forwarded through the Head of the Regional Office of the Provincial National Land Agency concerned.

If a deliberative settlement between the disputing parties is not reached, then if the resolution is unilaterally by the Head of the National Land Agency due to a re-examination of the juridical and physical data there is data error and the results of the research cannot be accepted by the disputing parties, the settlement is through an Administrative Court Country.

If after going through research it turns out that the state administrative decision issued by the state administrative officer is correct according to the law and according to the applicable procedure, the Head of the National Land Agency can also issue a decision rejecting the claims of a third party who object to the administrative decision of the State, as the consequence of the refusal means that the administrative decision issued by the State remains valid even though there are other parties who file a lawsuit at the local Court.

While waiting for a court decision, until there is a final legally binding decision, it is prohibited for the administrative official of the State concerned to make a transfer. This is intended to avoid problems in the future that cause losses to parties in litigation and third parties, for this reason state administrative officials in the relevant land sector must apply general principles of good governance, namely to protect all interested parties until their existence. a court decision that has permanent legal force.

Then, if a court decision has permanent legal force, the head of the land office of the local municipality / regency, through the Head of the Regional Office of the Provincial National Land Agency concerned, submits a request for revocation / cancellation of the decision on state administration that has been decided. The application must be accompanied by a report on all data relating to the subject and the burdens on the land as well as any existing problems. So anyone who feels that his interests have been harmed by the issuance of a certificate of land rights can file a cancellation of this right.

However, if an error occurs by the Village Head or Lurah regarding the land register book, it can be convicted based on Article 372 and Article 378. Fraud, is a crime that is included in the category aimed at property rights and other rights arising from property rights or in Dutch, it is called "misdrijven tegen de eigendom en de daaruit voortloeiende zakelijk 
rechten". This crime is regulated by Articles 378 to Article 394 of the Criminal Code. As formulated in Article 378 of the Criminal Code, fraud means an act with the intention of benefiting oneself or another person against the law by using a false name, false dignity, trickery or lies that can cause other people to easily surrender their goods, money or assets.

Embezzlement, according to the Criminal Code, is regulated in article 372, which includes embezzlement is the act of taking the property of another person partly or wholly) where control over the object already belongs to the perpetrator, but the possession occurs legally. For example, control of an item by a perpetrator occurs because the owner entrusts the goods. Or control of goods by the perpetrator occurs because of their duties or positions, for example, the goods custodian. The purpose of embezzlement is to have goods or money in his control where the goods / money basically belong to someone else. From the formulation of embezzlement as mentioned above, if it is detailed it consists of objective elements including the act of having an object which partly or wholly belongs to another person, which is under his control not due to crime, and subjective elements include deliberate embezzlement and embezzlement against the law. Whereas the responsibility of the Lurah and Village Heads in the land register book is for the sake of achieving civil justice order land administration, namely by applying the principle of actions against the law or onrechtmatige daad as applicable in Article 1365 of the Civil Code as well as administrative sanctions based on the provisions in Law Number 6 of 2014 Regarding the Village, namely in the form of warning, temporary notification until permanent discharge from the position of Village Head.

\section{Conclusion}

The responsibility of the Lurah and Village Heads in the land register book for the sake of achieving a just land administration order is criminal responsibility, namely based on the Criminal Code, Articles relating to land crimes include crimes against land grabbing as regulated in Article 167 of the Criminal Code, Crimes against Falsification of documents are regulated in Articles 263, 264, 266 and 274 of the Criminal Code as well as the crime of embezzlement of the right to immovable property such as land, house, rice fields. This crime is commonly referred to as stellionaat crime, which is regulated in Article 385 of the Criminal Code.

Civil accountability is by applying the principle of unlawful acts or onrechtmatige daad applicable in Article 1365 of the Civil Code as well as administrative sanctions based on the provisions of Law Number 6 of 2014 concerning Villages, namely in the form of warnings, temporary notification until permanent dismissal from the position of Village Head. So it is very necessary to improve counseling and guidance to the Village Head and village government officials regarding land regulations, especially those concerning the procedures for filling in land register books, maintaining and storing them, so as to know that the land register book is also an archive or stored privately. by the village head or village officials, thus obstructing the provision of services to communities in need as well as Physical data and juridical data that are announced at the Village Office should be filed or recorded, thereby minimizing the possibility for land that has been requested for certificate to be transferred to rights by using a copy. Letter $\mathrm{C}$ as the basis for ownership and the land book of land where land registration or certification has been carried out is noted regarding this matter.

\section{References}


Pewarisan Dalam Pembebanan Hak Tanggungan,” JUSTICIA SAINS J. Ilmu Huk., 2020.

[2] K. Harnadi, "Model Penguasaan Tanah oleh Masyarakat Desa Margosari dan Penyelesaiaannya pada Kawasan Hutan Lindung Register 22 Way Waya Kabupaten Pringsewu," Cepalo, 2019.

[3] U. Santoso, "JUAL-BELI TANAH HAK MILIK YANG BERTANDA BUKTI PETUK PAJAK BUMI (KUTIPAN LETTER C),” Perspektif, 2012.

[4] Soerjono Soekanto dan Sri Mamudji, Penelitian Hukum Normatif (Suatu Tinjauan Singkat). Jakarta: Rajawali Pers, 2001.

[5] Soerjono Soekanto, Sosiologi Suatu Pengantar. Jakarta: Rajawali Press, 2012.

[6] H. Ismi, "Pengakuan Dan Perlindungan Hukum Hak Masyarakat Adat Atas Tanah Ulayat Dalam Upaya Pembaharuan Hukum Nasional," J. Ilmu Huk. Riau, 2012.

[7] K. F. Kurnia and R. Santina, "Konstruksi Penyelesaian Pelanggaran Pemilihan Umum," JUSTICIA SAINS J. Ilmu Huk., 2018.

[8] M. S. W. Sumardjono, "Kebijakan Pertanahan Antara Regulasi dan Implementasi," Kompas, 2005. 